\title{
Analysis of Interactions Between Cassava Brown Streak Disease Symptom Types Facilitates the Determination of Varietal Responses and Yield Losses
}

I. L. Ndyetabula and S. M. Merumba, Maruku Agricultural Research Institute, Bukoba, Tanzania; S. C. Jeremiah and S. Kasele, Ukiriguru Agricultural Research Institute, Mwanza, Tanzania; G. S. Mkamilo, Naliendele Agricultural Research Institute, Mtwara, Tanzania; F. M. Kagimbo, Tumbi Agricultural Research Institute, Tabora, Tanzania; and J. P. Legg, International Institute of Tropical Agriculture, Dar es Salaam, Tanzania

\begin{abstract}
Ndyetabula, I. L., Merumba, S. M., Jeremiah, S. C., Kasele, S., Mkamilo, G. S., Kagimbo, F. S., and Legg, J. P. 2016. Analysis of interactions between cassava brown streak disease symptom types facilitates the determination of varietal responses and yield losses. Plant Dis. 100:1388-1396.

Cassava brown streak disease (CBSD), caused by cassava brown streak viruses, is recognized as one of the most important plant disease threats to African food security. This study describes the incidence and severity of the different symptom types caused by CBSD, derived from extensive surveys in the country most severely affected by the disease: Tanzania. Total plant incidence and mean root severity of CBSD, recorded from 341 farmers' fields, were both greater in the Coast Zone $(49.5 \%$ and 3.05 ), than in the Lake Zone ( $32.7 \%$ and 2.57 ). Overall, the differing incidences recorded declined in the following order: total plant incidence $(39.1 \%)$, plant shoot incidence $(33.4 \%)$, plant root incidence $(19.3 \%)$, root incidence (10.5\%), and unusable root incidence (5.4\%). The much lower-than-anticipated loss due to the root necrosis that is characteristic of CBSD was offset by large reductions of root number in plants

expressing foliar symptoms of CBSD (15.7\% in the Coast Zone and $5.5 \%$ in the Lake Zone). These data suggest that the effects of CBSD on the growth of affected plants are greater than those due to root spoilage. Based on these two factors, annual losses due to CBSD in the parts of Tanzania surveyed were estimated at $>860,000 \mathrm{t}$, equivalent to more than U.S.\$51 million. A novel approach to using farm-derived data on the responses of the most frequently cultivated varieties to CBSD infection allowed the grouping of the varieties into four categories, based on their relative resistance or tolerance to infection. This tool should be of value to breeders in identifying and selecting for sources of resistance or tolerance in both local and exotic germplasm, and should ultimately contribute to enhancing the management of one of Africa's most damaging crop diseases.
\end{abstract}

Cassava (Manihot esculenta Crantz) is a vital food security crop in large parts of sub-Saharan Africa. In East Africa, the largest area under cultivation is in Tanzania (FAOSTAT, 2014), although yields there are significantly lower than they are in neighboring Kenya and Uganda. The two virus diseases - cassava mosaic disease (CMD) and cassava brown streak disease (CBSD) - are the most important constraints to cassava production in Africa, and this status has been exacerbated in recent years by the expansion through East and Central Africa of a pandemic of unusually severe CMD, and new outbreaks of CBSD (Alicai et al. 2007; Legg et al. 2011; Otim-Nape et al. 1997). CBSD is caused by two species of cassava brown streak (CBS) viruses : Cassava brown streak virus (CBSV) and Ugandan cassava brown streak virus (UCBSV) (family, Potyviridae; genus, Ipomovirus) (Mbanzibwa et al. 2011b; Monger et al. 2001; Winter et al. 2010). CBS viruses are propagated through the use of cuttings from infected parent plants and are transmitted by the whitefly vector Bemisia tabaci (Maruthi et al. 2005).

CBSD was first reported in the 1930s (Storey 1936) from the northeastern part of what is now Tanzania but was later shown to occur throughout the coastal lowlands of East Africa, including the lakeshore areas of Malawi (Bock 1994; Legg and Raya 1998; Munga and Thresh 2002; Nichols 1950; Thresh and Mbwana 1998). Prior to 2004, CBSD was considered to be limited in its distribution to areas below 1,000 m above sea level (m.a.s.l.) (Hillocks et al. 1996; Nichols 1950), although there were several reports of low incidences of CBSD from Uganda (Nichols 1950), northwestern Tanzania (Legg and Raya 1998), and southern Uganda (Hillocks and Jennings 2003) - all locations significantly above 1,000 m.a.s.l. Since 2004, CBSD has spread throughout the Great Lakes region of East and

Corresponding author: J. P. Legg; E-mail: j.legg@cgiar.org

Accepted for publication 5 February 2016.

http://dx.doi.org/10.1094/PDIS-11-15-1274-RE

(c) 2016 The American Phytopathological Society
Central Africa, driven by unusually abundant populations of the whitefly vector (Legg et al. 2011). The widespread occurrence of CBSD in the Lake Zone area of the northwest of Tanzania was first noted in 2006 (Jeremiah 2012; Jeremiah and Legg 2008). Surveys conducted subsequently have revealed the continued expansion of the disease epidemic, affecting most of this major cassava-producing region of Tanzania (Jeremiah et al. 2015).

CBSD is an unusual virus disease, because it causes a diverse range of symptoms in leaves, stems, and tuberous roots (Nichols 1950). The most prominent aboveground symptoms occur on lower leaves and consist of a blotchy chlorotic mosaic or, more commonly, a feathery chlorosis associated with secondary and tertiary veins. Stem symptoms consist of elongated, dark-brown to black necrotic lesions on the green stem portions but, in severe infections, may progress to complete necrosis and dieback of the shoot (Jennings 1960; Nichols 1950). Symptoms in tuberous roots appear as dry and corky necrotic portions which, in early stages or mild infections, are small and sepia colored but, in later stages or severe infections, may result in dry brown to black rot affecting the entire root cortex (Hillocks and Thresh 2000).

CBSD does not typically have an obvious effect on the growth of cassava plants (Jennings 1960), and most of the yield losses are thought to be a consequence of the loss of tuberous roots that results from severe root rot rendering them unpalatable (Hillocks et al. 2001; Nichols 1950). Additionally, because rot is known to increase in severity as cassava plants mature, early harvesting - used by farmers to avoid the worst losses from rot-is widely practiced in CBSDaffected areas and leads to reduced yields and problems in maintaining planting material until the following planting season. Processing is also impaired, because rotten portions need to be removed from mildly affected tuberous roots. Most of these elements of loss remain unquantified, with the exception of a published yield loss estimate of $70 \%$ recorded for the most susceptible varieties (Hillocks et al. 2001).

The current study comprises the most extensive assessment of root symptoms of CBSD conducted to date. By examining shoot and root symptoms of plants in the fields of more than 300 farmers in the most 
important cassava-growing areas of Tanzania, it was anticipated that important insights would be obtained on the relationship between the various CBSD symptom types, the different responses to infection of the diverse cassava varieties being grown, and, ultimately, on the overall impact of CBSD infection in Tanzania-one of Africa's largest cassava producers and a country that relies heavily on this crop for sustaining food security.

\section{Materials and Methods}

Field sampling. The study was conducted in Tanzania from August to September 2009. In all, 36 districts were surveyed, including 23 from the Lake and Western Zones (hereafter referred to collectively as Lake Zone) and 13 in the Coast Zone (Fig. 1). In most districts, 10 fields were sampled, although there were fewer in districts where less cassava was encountered and more (11 fields) in one district. In total, 128 fields were sampled in the Coast Zone and 213 in the Lake Zone. Three- to six month-old cassava crops were selected at regular intervals of 6 to $10 \mathrm{~km}$ along motorable roads. In each sampled field, 10 plants of the predominant variety were sampled at regular intervals along the diagonals of an X-shaped transect. Field owners provided locational information and the name and age of the cassava variety being grown. Sampling site coordinates were recorded with a global positioning system unit (Garmin eTrex 10; Garmin International Inc., Olathe, KS).

Assessment of plants. The sampled plants were assessed for presence of CBSD symptoms on leaves, stems, and roots. On leaves, symptom severity was assessed using a scoring scale of 1 to 5 , where 1 represented no symptoms, $2=$ the mildest symptoms, and $5=$ the most severe symptoms (Hillocks and Thresh 2000). On stems, the occurrence of stem lesions was recorded as either present (+) or absent $(-)$. For the assessment of root symptoms, sampled plants were uprooted. Roots were counted, and each was then cut cross-sectionally five times at regular intervals along the length of the root. A symptom score was then recorded for each cut, using the 1-to-5 scoring scale of Hillocks and Thresh (2000).

Data analysis. For each field, district, and cassava variety, mean values were computed for plant total incidence (percentage of plants showing any of the three symptom types), plant shoot incidence (percentage of plants showing foliar or stem symptoms), plant root incidence (percentage of plants showing root symptoms), root incidence (percentage of tuberous roots showing symptoms), unusable root incidence (percentage of plants having one or more cross-sectional cut score of 3 or greater), and root severity (average for all symptomatic cross-sectional cut scores). District mean values for each of these

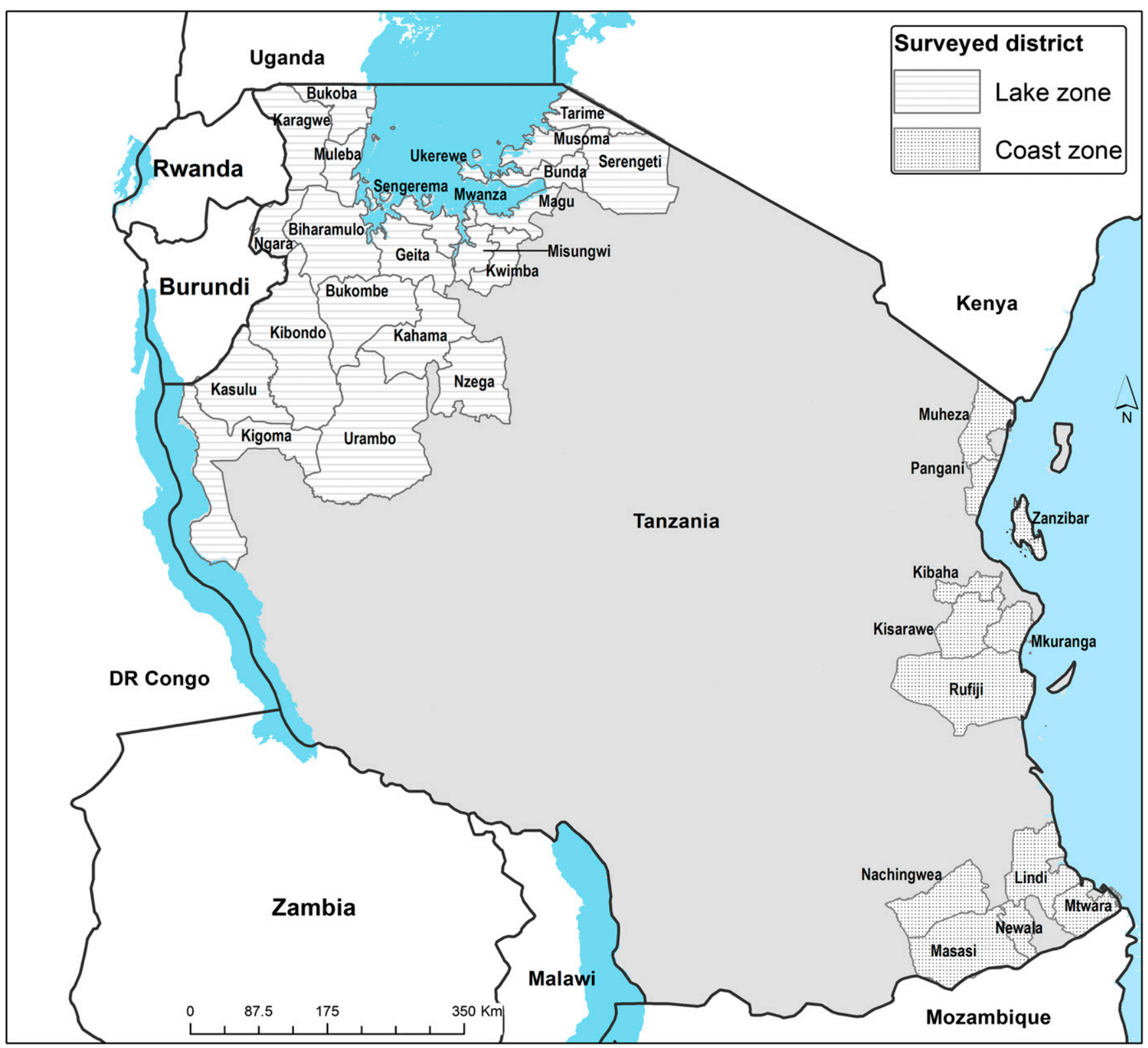

Fig. 1. Districts surveyed for cassava brown streak disease in Tanzania in 2009. 
scores were analyzed using Kruskal-Wallis one-way analysis of variance with the SigmaStat component of SigmaPlot 11.0 (Systat Inc., Chicago). Means were separated with Dunn's multiple comparison function. Regression analysis was used to examine relationships between incidence and severity variables. CBSD root severity values for districts in the Lake Zone with those in the Coast Zone were compared with $t$ tests, while differences in the proportions of symptom types between these two zones were tested with a $\chi^{2}$ contingency table analysis. The responses of different cassava varieties to CBSD were characterized by defining, then calculating "tolerance" and "resistance". For this purpose, tolerance was defined as the ratio between the level of shoot infection (= plant shoot incidence) and the incidence of unusable roots. The tolerance $(T)$ value for a given variety was the mean of each of the tolerance values for fields in which that variety occurred. Resistance (R) was defined for a given variety in a district as the mean plant total incidence for the district minus the plant total incidence for the field in which that variety was recorded. Resistance values for all fields in which a given variety was recorded were averaged to produce the mean resistance value for that variety.

\section{Results}

Variation in CBSD incidence and severity between zones and districts. CBSD is a complex plant virus disease which may give rise to symptom expression in one or more plant parts, including leaves, stems, and tuberous roots. In this study, comparisons were made between each of these symptom types, and their quantitative relationships were investigated. CBSD plant total incidence included plants with all possible symptom types and, consequently, always gave the highest value for any given field, variety, district, or zone. By contrast, plant shoot incidence and plant root incidence were either greater or less for a field, variety, district, or zone, depending on the circumstances. Overall, the 3,410 plants from the 341 surveyed sites had an average plant total incidence of $39.1 \%$. Other incidence values, in descending order, were plant shoot incidence $(33.4 \%)$, plant root incidence $(19.3 \%)$, root incidence $(10.5 \%)$, and unusable root incidence $(5.4 \%)$ (Table1).

CBSD was more important in the Coast than the Lake Zone in terms of both incidence and severity (Tables 1 and 2). Values for all of the main incidence categories were higher in the Coast than in the Lake Zone. The mean root severity value of 3.05 for the Coast Zone was significantly greater than the value of 2.57 for the Lake Zone $(t=3.67, \mathrm{df}=32, P<0.001)$. Furthermore, there was a significantly higher level of unusable root incidence $(8.6 \%)$ in the Coast Zone than in the Lake Zone $(3.4 \% ; t=2.72, \mathrm{df}=34, P=0.01)$. In the Coast Zone, the relative proportions of different incidence values varied between districts (Table 1) although, in general, districts with higher plant total incidence values also had high root incidence and unusable root incidence values. Two districts-Kibaha and Pangani-had significantly higher levels of plant total incidence than districts that had the least CBSD (Nachingwea and Newala) (Kruskal-Wallis: $\mathrm{H}=57.3, \mathrm{df}=12, P<0.001$ ). A similar but less significant contrast was also demonstrated for root incidence $(\mathrm{H}=46.4$, $\mathrm{df}=12, P<0.001)$. In the Lake Zone, Bunda, Musoma, and Ukerewe Districts had most CBSD plant total incidence, while Kwimba, Misungwi, Kibondo, and Bukombe had the least (Table 2; $\mathrm{H}=115.6$, df $=22, P<0.001)$. Significant differences between districts were also demonstrated for plant shoot incidence $(\mathrm{H}=150.2$, df $=22$, $P<0.001)$, plant root incidence $(\mathrm{H}=80.7, \mathrm{df}=22, P<0.001)$, root incidence $(\mathrm{H}=85.0, \mathrm{df}=22, P<0.001)$, and unusable root incidence ( $\mathrm{H}=65.2, \mathrm{df}=22, P<0.001)$. In contrast to the Coast Zone, 11 of the Lake Zone districts, toward the southern and western parts of the region, had incidences of root symptoms in the absence of any foliar symptoms, although these root incidences were typically low (Table 2; Fig. 1). The sequential pattern of decline in incidence values from the largest (plant total incidence) to the smallest (unusable root incidence) was similar for both the Coast and Lake Zones (Tables 1 and 2).

Relationships between CBSD incidence variables and root symptom severity. Linear regression was used to examine relationships between the various CBSD incidence variables and root symptom severity (Table 3 ). Using district-level data, a positive linear relationship was demonstrated between plant root incidence and plant shoot incidence (Fig. 2: $F=34.0, r^{2}=0.50$, df $=35, P<$ 0.001 ) and, similarly, between root severity and root incidence (Fig. 3: $F=31.2, r^{2}=0.29$, df $=33, P<0.001$ ). The gradient of the plant shoot versus plant root incidence regression indicates that, for a plant shoot incidence value of $100 \%$, the predicted plant root incidence is $42 \%$. Although significant variation about the regression line confirms that there are many cases where plant root incidences may be greater than or less than this figure for a plant shoot incidence value of $100 \%$, it illustrates the general outcome that, for a given amount of plant shoot incidence, there is typically less plant root incidence. Three districts that represent extreme cases of this are Mkuranga, Bagamoyo, and Rufiji, all from the Coast Zone (Fig. 2), where plant shoot incidences were moderate to high (36 to $71 \%$ ) but plant root incidences in all cases were very low $(<5 \%)$. A similar "outlier" was apparent from the root incidence versus root severity plot (Fig. 3), in which Mtwara District had a much higher mean severity value

Table 1. Distribution of cassava brown streak disease (CBSD) symptoms in the Coast Zone of Tanzania, 2009, and overall average for both Coast and Lake Zones $^{\mathrm{z}}$

\begin{tabular}{|c|c|c|c|c|c|c|c|}
\hline District & $\begin{array}{l}\text { Number of } \\
\text { fields }\end{array}$ & $\begin{array}{l}\text { Plant total } \\
\text { incidence }\end{array}$ & $\begin{array}{l}\text { Plant shoot } \\
\text { incidence }\end{array}$ & $\begin{array}{l}\text { Plant root } \\
\text { incidence }\end{array}$ & $\begin{array}{c}\text { Root } \\
\text { incidence }\end{array}$ & $\begin{array}{l}\text { Unusable root } \\
\text { incidence }\end{array}$ & $\begin{array}{c}\text { Root } \\
\text { severity }\end{array}$ \\
\hline Muheza & 8 & $50.0 \mathrm{ab}$ & $41.3 \mathrm{ab}$ & $38.8 \mathrm{ab}$ & $28.0 \mathrm{ab}$ & 15.6 & 2.66 \\
\hline Pangani & 10 & $91.0 \mathrm{a}$ & $85.0 \mathrm{a}$ & $47.0 \mathrm{a}$ & $24.8 \mathrm{a}$ & 15.3 & 2.92 \\
\hline Kibaha & 10 & $92.0 \mathrm{a}$ & $90.0 \mathrm{a}$ & $33.0 \mathrm{ab}$ & $22.5 \mathrm{ab}$ & 14.8 & 2.89 \\
\hline Bagamoyo & 10 & $60.0 \mathrm{ab}$ & $59.0 \mathrm{ab}$ & $4.0 \mathrm{ab}$ & $2.2 \mathrm{ab}$ & 1.1 & 2.58 \\
\hline Kisarawe & 10 & $57.0 \mathrm{ab}$ & $55.0 \mathrm{ab}$ & $15.0 \mathrm{ab}$ & $8.5 \mathrm{ab}$ & 6.1 & 2.95 \\
\hline Mkuranga & 10 & $73.0 \mathrm{ab}$ & $71.0 \mathrm{ab}$ & $4.0 \mathrm{ab}$ & $1.0 \mathrm{ab}$ & 0.5 & 2.58 \\
\hline Lindi & 10 & $69.0 \mathrm{ab}$ & $59.0 \mathrm{ab}$ & $29.0 \mathrm{ab}$ & $14.6 \mathrm{ab}$ & 9.4 & 3.14 \\
\hline Nachingwea & 10 & $7.0 \mathrm{~b}$ & $1.0 \mathrm{~b}$ & $6.0 \mathrm{ab}$ & $2.3 \mathrm{ab}$ & 0.3 & 2.12 \\
\hline Masasi & 10 & $51.0 \mathrm{ab}$ & $33.0 \mathrm{ab}$ & $45.0 \mathrm{ab}$ & $25.8 \mathrm{ab}$ & 16.9 & 2.66 \\
\hline Newala & 10 & $0 \mathrm{~b}$ & $0 \mathrm{~b}$ & $0 \mathrm{~b}$ & $0 \mathrm{~b}$ & 0 & $\ldots$ \\
\hline Mtwara & 10 & $12.0 \mathrm{~b}$ & $9.0 \mathrm{~b}$ & $12.0 \mathrm{ab}$ & $9.3 \mathrm{ab}$ & 7.4 & 3.80 \\
\hline Rufiji & 10 & $36.0 \mathrm{ab}$ & $36.0 \mathrm{ab}$ & $2.0 \mathrm{ab}$ & $1.1 \mathrm{ab}$ & 0.2 & 2.04 \\
\hline Zanzibar & 10 & $45.0 \mathrm{ab}$ & $45.0 \mathrm{ab}$ & $40.0 \mathrm{ab}$ & $30.0 \mathrm{ab}$ & 29.3 & 3.45 \\
\hline Mean (total) & $(128)$ & 49.5 & 45.0 & 20.9 & 12.2 & 8.6 & 3.05 \\
\hline Overall mean (total) & (341) & 39.1 & 33.4 & 19.3 & 10.5 & 5.4 & 2.85 \\
\hline
\end{tabular}

${ }^{\mathrm{z}}$ Plant total incidence $=$ percentage of plants with CBSD symptoms in either shoots or roots, Plant shoot incidence = percentage of plants with CBSD symptoms in shoots, Plant root incidence $=$ percentage of plants with CBSD symptoms in roots, Root incidence $=$ percentage of roots with CBSD symptoms, Unusable root incidence $=$ percentage of roots with at least one cut (out of five) with CBSD severity score 3 or more, and Root severity $=$ average severity of CBSD symptoms in cuts showing symptoms (i.e., cuts with scores 2 to 5). Lowercase letters indicate the results of Dunn's mean separation test. Values that do not share a common letter are significantly different at $P<0.05$. 
than all other districts. This result was strongly influenced by a single field that was cultivated with the highly CBSD-susceptible Supa, in which $98 \%$ of all roots were infected and more than $60 \%$ of those were in severity categories 4 and 5 .

Highly significant and positive linear relationships were demonstrated between plant total incidence, plant root incidence (Fig. 2), and root incidence, as well as between root incidence and root severity (Fig. 3).

Patterns of CBSD symptom expression in the Coast and Lake Zones. Patterns of CBSD symptom expression in leaves, stems, and roots differed between the Coast and Lake Zones $\left(\chi^{2}=19.4, \mathrm{df}=6\right.$, $P=0.004$; Fig. 4). In the Lake Zone, there were few plants with stem symptoms only or stem and root symptoms but a large proportion of plants (19.8\%) with only root symptoms. In the Coast Zone, there was a greater proportion of plants with leaf symptoms only, and stem symptoms - either alone or in combination with other symptom types-were more frequent than in the Lake Zone. Overall, leaf, stem, and root symptoms were present in 78,69 , and $42 \%$ of infected plants, respectively, in the Coast Zone and 80, 65, and 56\% of infected plants, respectively, in the Lake Zone.

Varietal responses to CBSD infection. Varieties differed greatly in their responses to CBSD infection. A comparison of patterns of symptom expression in the four most widely encountered varieties (Fig. 5) revealed that, whereas Lwakitangaza and Lyongo (both from the Lake Zone) had a high proportion of plants with root symptoms, Lumala (Lake Zone) and Kiroba (Coast Zone) had little root incidence, despite the fact that they both had high incidences of foliar symptoms. All common varieties (defined by their occurrence in three or more fields encountered during the survey) were categorized based on a combination of their tolerance and resistance responses to CBSD (Table 4; Fig. 6). Relative resistance or tolerance characteristics of these common varieties were visualized by plotting $\mathrm{R}$ and $\mathrm{T}$ values for each variety on a graph of $\mathrm{R}$ ( $\mathrm{Y}$ axis) against $\mathrm{T}$ ( $\mathrm{X}$ axis). Two approaches were considered for categorizing the varieties into groups, based on their resistance or tolerance values. In the first, values were almost equally split into four groups by a vertical line at $\mathrm{T}=$ 20 and a horizontal line at $\mathrm{R}=0$. A more appropriate categorization into contrasting levels of $\mathrm{R}$ and $\mathrm{T}$, however, was provided by the angled lines: (i) $\mathrm{R}=60-\mathrm{T}$, (ii) $\mathrm{R}=30-\mathrm{T}$, and (iii) $\mathrm{R}=-\mathrm{T}$. Category I varieties (those with the greatest combined levels of resistance and tolerance) were all above line (i), category II varieties (with moderate levels of resistance and tolerance) were between lines (i) and (ii), category III varieties (with low levels of resistance and tolerance) were between lines (ii) and (iii), and category IV varieties (with the lowest combined tolerance and resistance) were below line (iii). Three varieties were not classified in this way (Kalinda, Mabale, and Mware) because they had no CBSD incidence. Five category 1 (best) varieties were identified, of which Lumala was the most frequently cultivated.

Table 2. Distribution of cassava brown streak disease (CBSD) symptoms in the Lake Zone of Tanzania, 2009

\begin{tabular}{|c|c|c|c|c|c|c|c|}
\hline District & $\begin{array}{l}\text { Number of } \\
\text { fields }\end{array}$ & $\begin{array}{l}\text { Plant total } \\
\text { incidence }\end{array}$ & $\begin{array}{l}\text { Plant shoot } \\
\text { incidence }\end{array}$ & $\begin{array}{l}\text { Plant root } \\
\text { incidence }\end{array}$ & $\begin{array}{c}\text { Root } \\
\text { incidence }\end{array}$ & $\begin{array}{c}\text { Unusable } \\
\text { root incidence }\end{array}$ & $\begin{array}{c}\text { Root } \\
\text { severity }\end{array}$ \\
\hline Geita & 9 & $16.7 \mathrm{ab}$ & $8.9 \mathrm{ab}$ & $8.9 \mathrm{ab}$ & $3.6 \mathrm{ab}$ & 1.0 & 2.38 \\
\hline Sengerema & 10 & $35.0 \mathrm{ab}$ & $32.0 \mathrm{ab}$ & $26.0 \mathrm{ab}$ & $21.7 \mathrm{ab}$ & 8.7 & 2.53 \\
\hline Misungwi & 10 & $1.0 \mathrm{~b}$ & $0 \mathrm{ab}$ & $1.0 \mathrm{~b}$ & $0.3 \mathrm{~b}$ & 0 & 2.00 \\
\hline Magu & 10 & $59.0 \mathrm{ab}$ & $55.0 \mathrm{ab}$ & $31.0 \mathrm{ab}$ & $17.9 \mathrm{ab}$ & 4.8 & 2.29 \\
\hline Kwimba & 6 & $0 \mathrm{~b}$ & $0 \mathrm{ab}$ & $0 \mathrm{~b}$ & $0 \mathrm{~b}$ & 0 & - \\
\hline Ukerewe & 11 & $94.0 \mathrm{a}$ & $94.0 \mathrm{a}$ & $45.0 \mathrm{a}$ & $21.5 \mathrm{a}$ & 6.1 & 2.62 \\
\hline Mwanza & 4 & $75.0 \mathrm{ab}$ & $75.0 \mathrm{ab}$ & $32.5 \mathrm{ab}$ & $23.4 \mathrm{ab}$ & 1.1 & 2.10 \\
\hline Musoma & 10 & $98.0 \mathrm{a}$ & $98.0 \mathrm{a}$ & $55.0 \mathrm{a}$ & $31.3 \mathrm{a}$ & 15.6 & 2.97 \\
\hline Serengeti & 10 & $71.0 \mathrm{ab}$ & $66.0 \mathrm{ab}$ & $17.0 \mathrm{ab}$ & $9.3 \mathrm{ab}$ & 2.1 & 2.16 \\
\hline Kigoma & 10 & $9.0 \mathrm{ab}$ & $0 \mathrm{~b}$ & $9.0 \mathrm{ab}$ & $3.4 \mathrm{ab}$ & 0.6 & 2.31 \\
\hline Kibondo & 10 & $1.0 \mathrm{~b}$ & $0 \mathrm{ab}$ & $1.0 \mathrm{~b}$ & $0.2 \mathrm{~b}$ & 0 & 2.0 \\
\hline Kasulu & 10 & $15.0 \mathrm{ab}$ & $0 \mathrm{ab}$ & $15.0 \mathrm{ab}$ & $4.5 \mathrm{ab}$ & 0.2 & 2.02 \\
\hline Karagwe & 4 & $12.5 \mathrm{ab}$ & $0 \mathrm{ab}$ & $12.5 \mathrm{ab}$ & $5.0 \mathrm{ab}$ & 0.5 & 2.33 \\
\hline Biharamulo & 10 & $26.0 \mathrm{ab}$ & $14.0 \mathrm{ab}$ & $16.0 \mathrm{ab}$ & $8.1 \mathrm{ab}$ & 3.2 & 2.60 \\
\hline Bukoba & 9 & $10.0 \mathrm{ab}$ & $0 \mathrm{ab}$ & $10.0 \mathrm{ab}$ & $4.0 \mathrm{ab}$ & 2.2 & 2.42 \\
\hline Ngara & 10 & $9.0 \mathrm{ab}$ & $0 \mathrm{ab}$ & $9.0 \mathrm{ab}$ & $3.1 \mathrm{ab}$ & 0.3 & 2.12 \\
\hline Muleba & 10 & $16.0 \mathrm{ab}$ & $10.0 \mathrm{ab}$ & $16.0 \mathrm{ab}$ & $8.3 \mathrm{ab}$ & 5.3 & 2.54 \\
\hline Nzega & 10 & $10.0 \mathrm{ab}$ & $0 \mathrm{~b}$ & $10.0 \mathrm{ab}$ & $3.3 \mathrm{ab}$ & 1.1 & 2.12 \\
\hline Urambo & 10 & $16.0 \mathrm{ab}$ & $0 \mathrm{ab}$ & $16.0 \mathrm{ab}$ & $5.5 \mathrm{ab}$ & 2.6 & 2.49 \\
\hline Bukombe & 10 & $2.0 \mathrm{~b}$ & $0 \mathrm{ab}$ & $2.0 \mathrm{~b}$ & $0.6 \mathrm{~b}$ & 0.4 & 2.00 \\
\hline Kahama & 10 & $12.0 \mathrm{ab}$ & $0 \mathrm{ab}$ & $12.0 \mathrm{ab}$ & $5.2 \mathrm{ab}$ & 0 & 2.00 \\
\hline Tarime & 10 & $66.0 \mathrm{ab}$ & $61.0 \mathrm{ab}$ & $13.0 \mathrm{ab}$ & $5.2 \mathrm{ab}$ & 2.6 & 2.45 \\
\hline Bunda & 10 & $86.0 \mathrm{a}$ & $81.0 \mathrm{ab}$ & $55.0 \mathrm{a}$ & $33.8 \mathrm{a}$ & 12.0 & 2.79 \\
\hline Mean (total) & (213) & 32.7 & 26.2 & 18.3 & 9.3 & 3.4 & 2.57 \\
\hline
\end{tabular}

z Plant total incidence $=$ percentage of plants with CBSD symptoms in either shoots or roots, Plant shoot incidence $=$ percentage of plants with CBSD symptoms in shoots, Plant root incidence $=$ percentage of plants with CBSD symptoms in roots, Root incidence $=$ percentage of roots with CBSD symptoms, Unusable root incidence $=$ percentage of roots with at least one cut (out of five) with score 3 or more, and Root severity = Average severity of symptoms in cuts showing symptoms (i.e., cuts with scores 2 to 5). Lowercase letters indicate the results of Dunn's mean separation test. Values that do not share a common letter are significantly different at $P<0.05$.

Table 3. Summary of regression analyses examining relationships between different cassava brown streak disease incidence and severity variables for field-level data from both the Coast and Lake Zones, 2009

\begin{tabular}{llccrrrr}
\hline Factor 1 & \multicolumn{1}{c}{ Factor 2} & $\boldsymbol{N}$ & Coefficient & Constant & $\boldsymbol{r}^{\mathbf{2}}$ & $\boldsymbol{F}$ value & $\boldsymbol{P}$ value \\
\hline Plant total incidence & Plant root incidence & 341 & 0.99 & 19.9 & 0.45 & 280.0 & $<0.001$ \\
Plant total incidence & Root incidence & 341 & 1.24 & 25.2 & 0.36 & 188.7 & $<0.001$ \\
Plant total incidence & Unusable root incidence & 341 & 1.27 & 31.7 & 0.21 & 88.3 & $<0.001$ \\
Plant total incidence & Root severity & 157 & 16.7 & 27.0 & 0.06 & 10.3 & 0.002 \\
Root incidence & Root severity & 157 & 22.7 & -31.4 & 0.23 & 47.4 & $<0.001$ \\
Unusable root incidence & Root severity & 157 & 25.0 & -48.5 & 0.40 & 104.0 \\
\hline
\end{tabular}


Most of these varieties had high tolerance values and, consequently, their root severity scores and incidences of unusable roots were some of the lowest. Mkombozi, a recently released CMD-resistant variety, was included in category 1 . The most widely cultivated variety in the second category was Kiroba, a research-promoted variety widely recognized for its tolerance to CBSD. Varieties in the least-favorable grouping (category 4 ) were characterized by low tolerance values and very low resistance values, signifying their higher-than-average incidences of infection when compared with other varieties in the same district. Of the three unclassified varieties, Mwari from Zanzibar had the highest of all resistance values because it was uninfected whereas other varieties from Zanzibar had relatively high CBSD incidences. Regression analysis showed that there was no linear relationship between tolerance and resistance $(F=0.02, \mathrm{df}=30, P=0.89)$. This result was expected, because high tolerance values occurred where plant total incidence was high yet unusable root incidence low, while high plant total incidence commonly resulted in low resistance values.

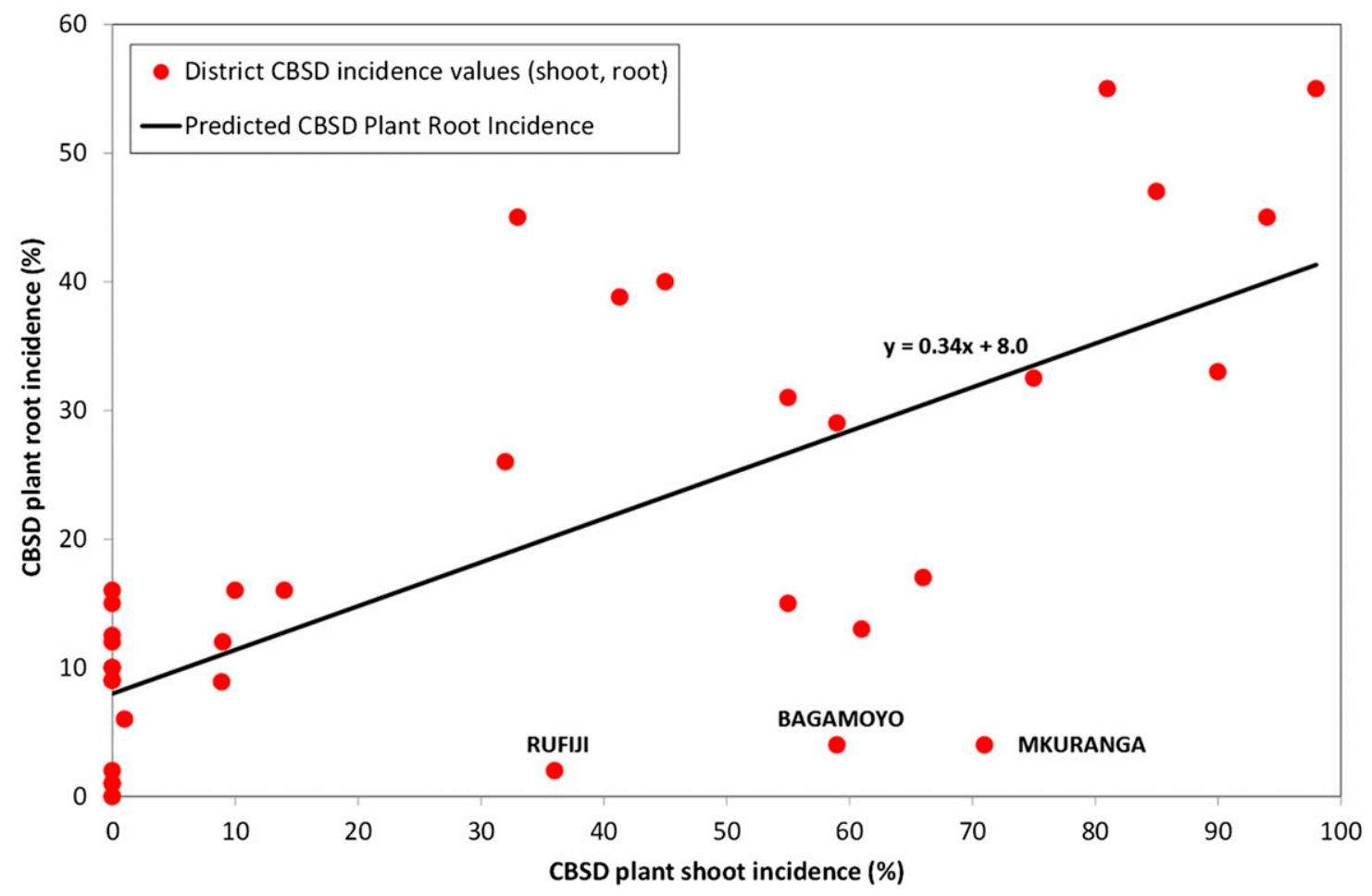

Fig. 2. Relationship between cassava brown streak disease (CBSD) shoot plant incidence and root plant incidence.

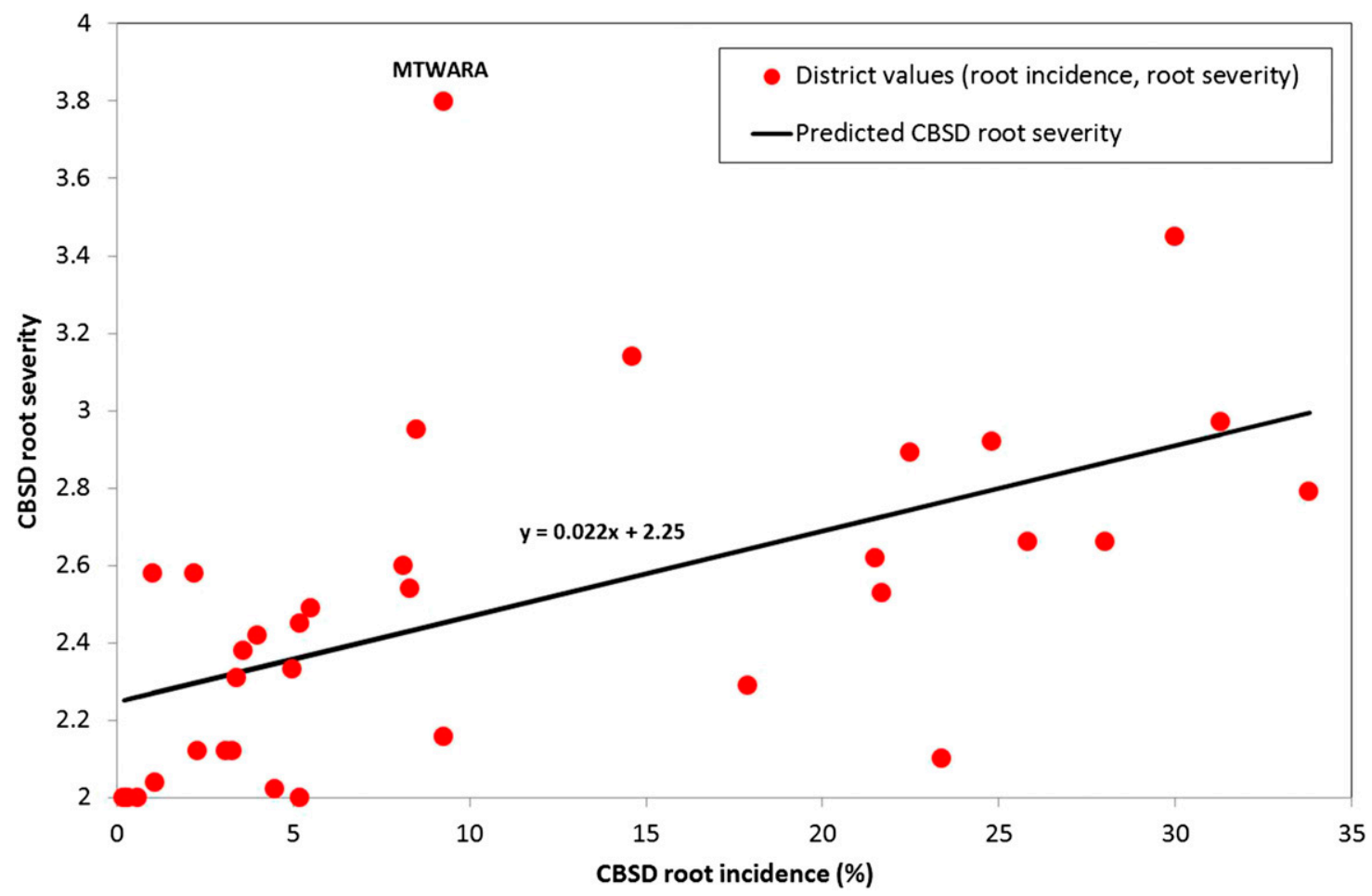

Fig. 3. Relationship between cassava brown streak disease (CBSD) root incidence and root severity. 
Estimating production loss due to CBSD infection. Unusable root incidence provides a direct estimate of tuberous root loss due to CBSD infection. Using this indicator, losses were significantly greater in the Coast Zone (8.6\%) than the Lake Zone $(3.4 \%)(t=$ 2.72 , $\mathrm{df}=34, P=0.01$; Tables 1 and 2 ), although there was considerable variation between districts. In the Coast Zone, losses were greatest in Zanzibar (29.3\%) and the districts of Masasi, Kibaha, Muheza, and Pangani (Table 1) whereas, in the Lake Zone, they were greatest in districts on the eastern shores of Lake Victoria: Musoma (15.6\%) and Bunda (12.0\%) (Table 2). Because CBSD also damages aboveground plant parts, including both leaves and stems, it is also anticipated that infected plants suffer further losses associated with reduced root weight. Root weight was not recorded in the current study; however, root number is commonly used as a proxy for root weight because the two are strongly positively correlated. Comparisons of root number in fields with and without foliar symptoms of CBSD revealed higher numbers of roots in fields without CBSD in both the Coast and Lake Zone. In the Coast Zone, there were 43 fields without foliar symptoms of CBSD, with an average root number per plant of 5.7. The 85 symptomatic fields in the same zone had an average root number per plant of 4.3. In the Lake Zone, the 102 asymptomatic fields had an average root number per plant of 4.4, while the 111 symptomatic fields had an average root number per plant of 4.1. Overall, average root number per plant was 4.8 for the 145 asymptomatic fields and 4.2 for the symptomatic fields, representing a "loss" of roots in symptomatic fields of $11.8 \%$ (15.7\% in the Coast Zone and $5.5 \%$ in the Lake Zone). Combining estimated losses due to unusable roots and root number reduction gives values of all zones $=17.2 \%$, Coast Zone $=24.3 \%$, and Lake Zone $=8.9 \%$. Total fresh weight production of cassava in 2007-08 was 1,944,052 $\mathrm{t}$ (from

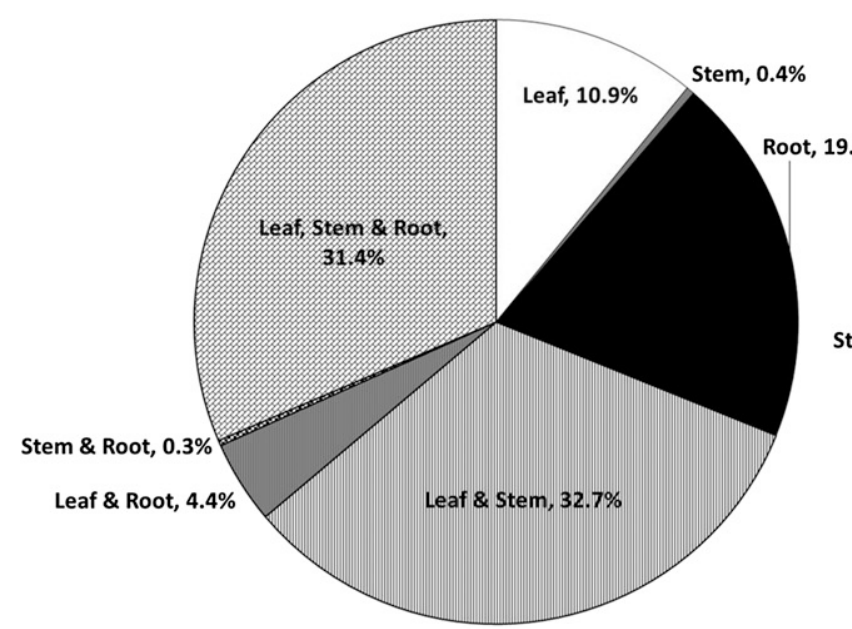

Lake Zone

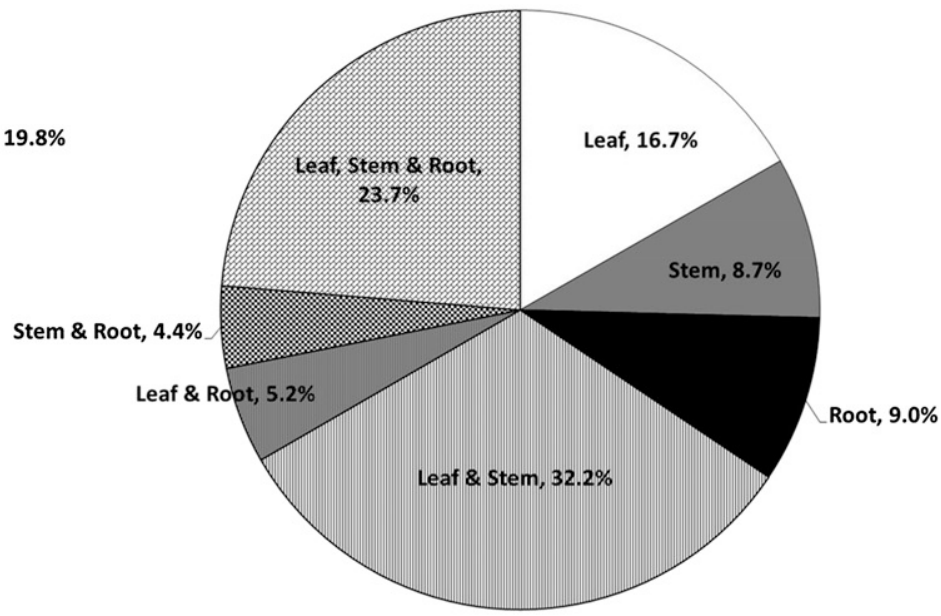

Coast Zone

Fig. 4. Frequencies of cassava brown streak disease symptom types in the Lake and Coast Zones of Tanzania.

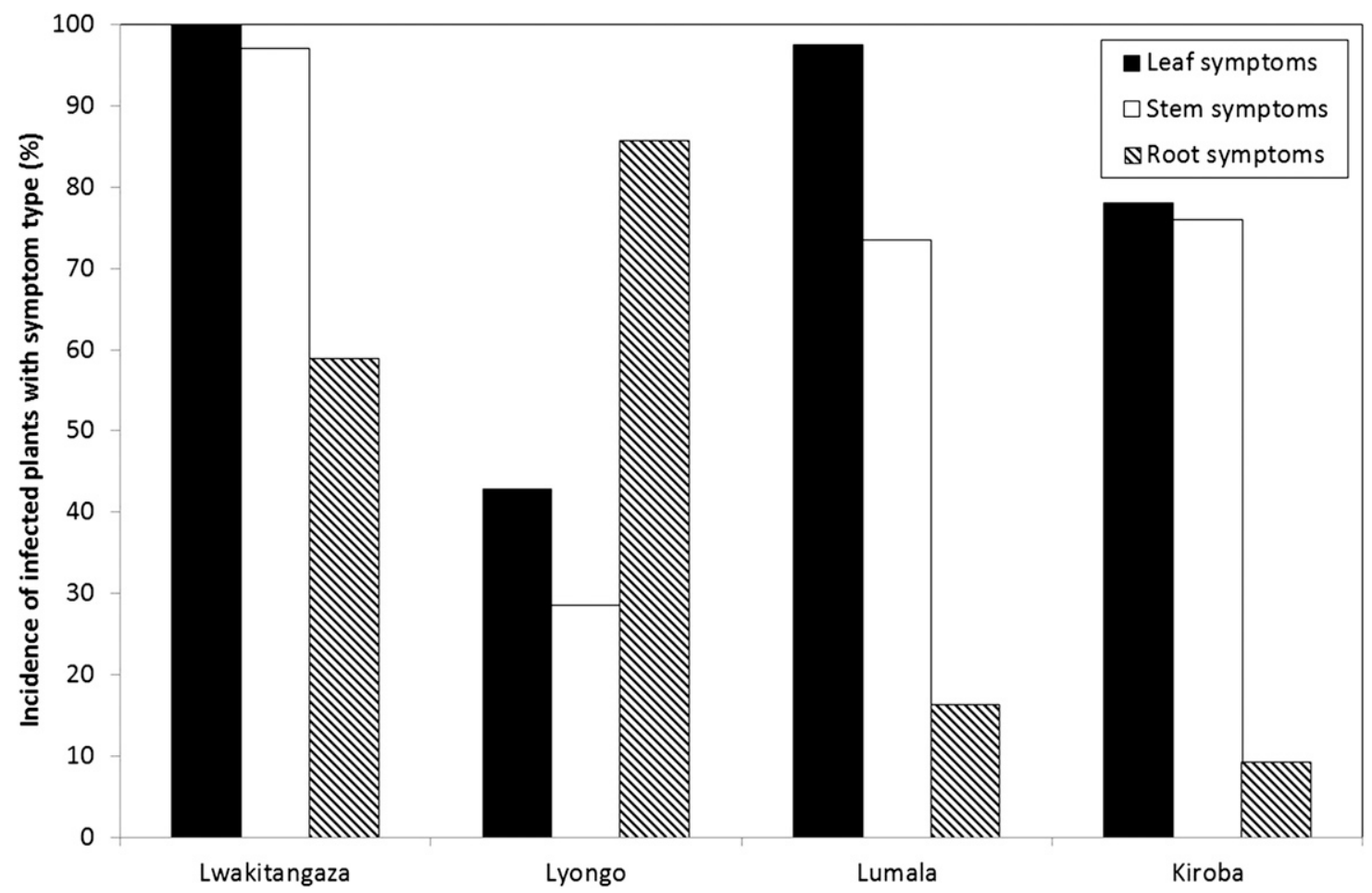

Fig. 5. Contrasting patterns of cassava brown streak disease symptom expression (percent whole-plant incidence) in the most commonly grown varieties in the Coast and Lake Zones of Tanzania, 2009. 
314,627 ha) in the Coast Zone and 2,432,729 t (from 390,334 ha) in the Lake Zone (Government of Tanzania 2012). Based on these figures, we can estimate production losses in the Coast Zone of 624,048 $\mathrm{t}$ and in the Lake Zone of 237,665 t, giving an overall total for the two zones of 861,713 t. Using a fresh-market value of 125 Tanzania shillings per kg of tuberous roots (Sewando 2012), equivalent to approximately U.S.\$60/t at current exchange rates, we obtain an economic value for these field-based losses to CBSD of U.S.\$51,702,780. This equates to an annual loss per hectare of U.S.\$73.

\section{Discussion}

CBSD is one of the greatest challenges facing researchers, agricultural workers, and farmers in East and Central Africa, and has been recognized globally as one of the seven most important disease threats to food security (Pennisi 2010). This problem has become particularly acute over the last decade. New outbreaks were reported for the first time from upland areas of the Great Lakes region of East Africa (Alicai et al. 2007). Superabundant populations of the whitefly vector $B$. tabaci are driving a pandemic of CBSD through East and Central Africa and westward toward the heartlands of Africa's cassava production zone in the Democratic Republic of Congo and Nigeria, the world's largest cassava producer (Legg et al. 2011, 2015; Patil et al. 2015). The current study emphasizes the growing importance of CBSD in the northwestern part of Tanzania, one of the countries most affected by this new pandemic. The emergence of CBSD in the areas surrounding Lake Victoria (approximately 1,150 m.a.s.1.) has been described elsewhere (Jeremiah et al. 2015; Legg et al. 2011). Results presented in this study confirm earlier observations that, although the occurrence of CBSD in the Lake Zone of Tanzania is almost entirely new, there has also been a significant increase in incidence in the Coast Zone (Jeremiah et al. 2015; Legg and Raya 1998), which is the part of the country that had been known to be affected by CBSD since the 1930s (Storey 1936). Incidences of foliar CBSD symptoms recorded by Jeremiah et al. (2015) in young plants ( $<6$ months old) of $46.5 \%$ in the Coast Zone and $22.6 \%$ in the Lake Zone were very similar to the values recorded in this study for mature plants ( $>10$ months old; $45.0 \%$ in the Coast Zone and $26.2 \%$ in the Lake Zone). In addition, there was a similar pattern of disease severity observed in both studies, in which foliar and root severities were both greater in the Coast Zone than they were in the Lake Zone. The fact that these two datasets were so closely comparable strengthens the validity of both and emphasizes the importance of the more widespread and severe CBSD disease situation that they present.

CBSD is an unusual virus disease, in that it elicits varied symptoms in different parts of the plant (Nichols 1950). Consequently, recording and scoring those symptoms is relatively more difficult than it is for other virus diseases, such as CMD. The current study represents the first attempt to make quantitative comparisons

Table 4. Incidences of cassava brown streak disease (CBSD) for popular cassava varieties grown in Tanzania, 2009y

\begin{tabular}{|c|c|c|c|c|c|c|c|c|c|}
\hline Variety ${ }^{z}$ & Field & Primary districts & Plant & Shoot & Root & Sev & Unusable & Tol & Res \\
\hline \multicolumn{10}{|l|}{$\overline{\text { Category I }}$} \\
\hline Lumala & 11 & Serengeti & 71.9 & 71.9 & 11.8 & 2.0 & 0 & 98.8 & -19.7 \\
\hline Cosmas & 3 & Mkuranga & 70.0 & 66.7 & 3.3 & 2.0 & 0 & 70.0 & 3.0 \\
\hline Lufaili & 4 & Sengerema & 15.0 & 15.0 & 0 & $\ldots$ & 0 & 60.0 & 11.5 \\
\hline Mkombozi & 3 & Ukerewe & 66.7 & 66.7 & 30.0 & 2.0 & 0.6 & 68.7 & -4.0 \\
\hline Bintindope & 5 & Bagamoyo, Kibaha & 100 & 100 & 10.0 & 2.7 & 0.7 & 84.4 & -20.8 \\
\hline \multicolumn{10}{|l|}{ Category II } \\
\hline Masengete & 3 & Bunda & 70.0 & 70.0 & 20.0 & 2.0 & 0 & 46.2 & 12.7 \\
\hline Kibandameno & 5 & Pangani & 46.0 & 36.0 & 36.0 & 2.3 & 3.7 & 29.9 & 28.8 \\
\hline Kiroba & 16 & Mkuranga, Rufuji & 60.0 & 60.0 & 5.6 & 2.7 & 0.6 & 60.0 & -4.6 \\
\hline Kikombe & 3 & Kisarawe & 26.7 & 20.0 & 13.3 & 2.7 & 3.2 & 21.9 & 30.3 \\
\hline Kirati & 8 & Musoma & 26.0 & 20.0 & 26.0 & 2.1 & 5.4 & 45.3 & 5.6 \\
\hline Rasta & 3 & Kisarawe & 40.0 & 40.0 & 6.6 & 2.3 & 0.9 & 31.0 & 17.0 \\
\hline Visenti & 3 & Lindi & 43.3 & 20.0 & 23.3 & 2.5 & 5.3 & 32.1 & 6.7 \\
\hline Zagazaga & 3 & Biharamulo & 13.3 & 13.3 & 0 & $\ldots$ & 0 & 29.5 & 3.6 \\
\hline Kiguzo & 6 & Pangani & 99.7 & 91.7 & 45.0 & 2.5 & 12.3 & 36.8 & -5.7 \\
\hline \multicolumn{10}{|l|}{ Category III } \\
\hline Lyongo & 21 & Kwimba, Misungwi & 6.7 & 2.9 & 5.7 & 2.0 & 0 & 23.3 & 2.9 \\
\hline Obaradak & 3 & Rorya & 80.0 & 66.7 & 40.0 & 2.3 & 11.9 & 35.9 & -14.0 \\
\hline Lwakitangaza & 15 & Ukerewe & 76.0 & 76.0 & 46.7 & 2.5 & 3.2 & 27.6 & -6.4 \\
\hline Limbukwa & 3 & Masasi & 36.6 & 33.3 & 20.0 & 2.7 & 6.2 & 4.3 & 14.3 \\
\hline Mwanzakilago & 3 & Urambo & 10.0 & 0 & 10.0 & 2.0 & 0.9 & 11.4 & 4.0 \\
\hline Tandika & 6 & Kasulu & 25.0 & 0 & 25.0 & 2.0 & 0.4 & 25.0 & -10.0 \\
\hline Musa said & 6 & Mtwara & 1.7 & 0 & 1.7 & 3.0 & 0.4 & 3.1 & 10.3 \\
\hline Kabumba & 5 & Kahama & 26.0 & 0 & 26.0 & 2.0 & 0 & 26.0 & -14.4 \\
\hline Mwanaidi & 4 & Kigoma & 2.5 & 0 & 2.5 & 3.3 & 1.0 & 2.1 & 6.5 \\
\hline Kachongoma & 3 & Musoma & 100 & 100 & 46.7 & 3.1 & 15.3 & 10.4 & -6.0 \\
\hline Ismail & 5 & Geita & 10.0 & 0 & 10.0 & 2.0 & 0 & 11.2 & -8.6 \\
\hline \multicolumn{10}{|l|}{ Category IV } \\
\hline Sheria & 6 & Nachingwea & 36.7 & 31.7 & 26.7 & 3.1 & 11.8 & 5.0 & -9.0 \\
\hline Mwasunga & 4 & Nzega & 23.2 & 0 & 23.2 & 2.8 & 4.0 & 5.2 & -11.3 \\
\hline Mreteta & 6 & Masasi, Nachingwea & 41.6 & 38.3 & 40.0 & 2.6 & 20 & 2.4 & -12.7 \\
\hline Supa & 3 & Lindi & 76.7 & 70.0 & 50.0 & 3.3 & 35.1 & 5.7 & -26.7 \\
\hline Agriculture & 4 & Zanzibar & 75.0 & 75.0 & 75.0 & 3.4 & 73.3 & 1.01 & -30.0 \\
\hline \multicolumn{10}{|l|}{ No category } \\
\hline Kalinda & 4 & Newala & 0 & 0 & 0 & $\ldots$ & 0 & $\ldots$ & $\ldots$ \\
\hline Mabale & 6 & Muleba & 0 & 0 & 0 & $\ldots$ & 0 & $\ldots$ & 16.2 \\
\hline Mwari & 4 & Zanzibar & 0 & 0 & 0 & $\cdots$ & 0 & $\cdots$ & 45.0 \\
\hline
\end{tabular}

${ }^{\mathrm{y}}$ Field $=$ field number, Plant $=$ percentage of plants with CBSD symptoms in either shoots or roots, Shoot = percentage of plants with CBSD symptoms in shoots, Root $=$ percentage of plants with CBSD symptoms in roots, Sev = average severity of symptoms in cuts showing symptoms, Unusable = percentage of roots with at least one cut (out of five) with score 3 or more, $\mathrm{Tol}=$ tolerance, and Res $=$ resistance.

${ }^{\mathrm{z}}$ Variety names in italics indicate those that have been officially released. 
between the various approaches to recording incidence of CBSD and, as such, should be of particular value to breeders looking to identify mechanisms of resistance and field practitioners looking for the most appropriate method for determining the impact of the disease. Through measuring whole-plant shoot incidence, wholeplant root incidence, root incidence, and unusable root incidence for a large number of local and research-promoted cassava varieties, it was possible to identify important trends in these incidence categories. Although there were some instances where root incidence was encountered in the absence of foliar incidence, the overwhelming trend from the complete dataset was that the level of foliar incidence was typically twice that of root incidence. Linear regression relationships between incidence and severity categories revealed that, where whole-plant shoot incidence was $100 \%$, plant root incidence was predicted to be $42 \%$ (Fig. 2). The first study to unequivocally prove the association between root necrosis and foliar symptoms of CBSD (Hillocks et al. 1996) also noted that, whereas $79 \%$ of plants with foliar symptoms also had root symptoms, $18 \%$ of plants with no leaf symptoms had root symptoms. More recently, a similar phenomenon has been associated with some of the most CBSD-resistant varieties (Kaweesi et al. 2014), in which foliar symptoms were absent while root symptoms were mild but frequent. An important feature of CBSD root symptoms is their heightened severity with increasing maturity of the plant. Early studies pointed this out (Nichols 1950), and it was recognized during this period that farmers used early harvesting as a strategy to minimize losses due to CBSD (Childs 1957). The average age of fields assessed in the current study was 12.7 months, an age by which symptoms would be expected to be present in infected plants, although severity would be anticipated to increase as plants aged further.

Patterns of the different incidence variables differed between districts. Most notably, Mkuranga, Rufiji, and Bagamoyo Districts in Coast Zone all had relatively low root incidences for their respective shoot incidences. This is most likely a consequence of the widespread cultivation of the released variety Kiroba (Anonymous 2015), which is noted for being tolerant to CBSD, in the sense that symptoms are expressed in the leaves but rarely present in roots. Data from this study confirm that Kiroba was the most widely cultivated variety in the Coast Zone and the second most common variety overall.

Important differences were noted in the balance of symptom types between the two zones. The greater severity of CBSD in coastal Tanzania was recorded by Jeremiah et al. (2015) but no reference was made to patterns of symptom expression in shoots, stems, and roots. Here, we observed that stem symptoms - commonly considered to be a feature of more severe infection by CBS viruses-were much more frequent in the Coast Zone than they were in the Lake Zone, while there was a large proportion of plants in the Lake Zone that only had root symptoms. Experiments conducted under controlled conditions have illustrated how varieties may differ greatly in their responses to CBS viruses and consequent patterns of symptom expression (Kaweesi et al. 2014), and it is likely that varietal variability is an important determinant of variation in patterns of CBSD symptom expression between regions. However, virus species and strains are also likely to have a significant influence on these symptom expression patterns, because their distributions are not uniform (Mbanzibwa et al. 2011a,b) and species and strains have differing virulence characteristics. Evidence has been presented to suggest that, in general, CBSV is more virulent than UCBSV (Kaweesi et al. 2014; Mohammed et al. 2012; Winter et al. 2010) and, of six isolates (three UCBSV isolates and three CBSV isolates) compared under controlled conditions with graft inoculations to virus-free plants, all three CBSV isolates produced more severe disease than the UCBSV isolates, and the most severe of the three CBSV isolates originated from Naliendele in Mtwara District, southern Tanzania. Because farmers have been selecting for tolerance to CBSD for many decades in coastal Tanzania, and this has been the focus area for CBSD control interventions through dissemination of tolerant varieties such as Kiroba, it would be expected that symptoms would be relatively less severe here than the Lake Zone region, in which farmers have had almost no time to select for tolerance and there has been minimal intervention thus far to mitigate the new outbreak. The fact that CBSD is more severe in the Coast Zone in spite of these circumstances strengthens the evidence for the occurrence of more severe strains of CBS viruses in this region. Other studies have noted coastal strains of CBSV to be some of the most severe of the CBSD-causing viruses (Mohammed et al. 2012).

Four categories of variety were identified based on the relative proportions of severe root incidence to shoot incidence (tolerance) and the shoot incidence of the variety when compared with other varieties in the district (resistance). This represents a novel approach to determining resistance or tolerance from data obtained from field-sampled plots of farmers' cassava varieties. Only two of the varieties encountered during the survey were officially released varieties (Mkombozi from the Lake Zone and Kiroba from the Coast Zone), and these were in categories I (best) and II, respectively. There was no clear regional trend in the distribution of varieties within the four categories, although there were slightly more coastal varieties in category IV (4 of 5) and slightly more Lake Zone varieties in category I (3 of 5). This is not surprising, in view of the generally greater severity of CBSD in the Coast Zone compared with the Lake Zone. In order to allow for this factor of variation, an alternative approach would be to do a similar categorization exercise for the two zones separately. Kaweesi et al. (2014) used a similar approach, albeit using virus load and field symptoms. The four categories identified were (i) low symptom expression, low virus load; (ii) moderate symptom expression, low virus load; (iii) low symptom expression, high virus load; and (iv) high symptom expression, high virus load. Both approaches seem to highlight the fact that cassava varieties possess different mechanisms through which they respond to infection by CBS viruses; some restrict the replication of infecting viruses, which typically leads to reductions in symptom expression, while others have mechanisms to minimize the effects of moderate to high virus loads on the expression of symptoms that are harmful to the productivity of the plant. Both methods, therefore, have value in guiding researchers toward potentially valuable sources of resistance to CBS viruses. Some progress has already been made in identifying some of the genes that are associated with resistance responses to CBS viruses (Maruthi et al. 2014) but it is certain that the rapid advances now being made in sequencing and genomics techniques will ensure that it becomes increasingly easy to characterize and then make use of resistance genes in germplasm development programs.

The survey data facilitated the estimation of field-based production losses to CBSD in the Lake and Coast Zones of Tanzania equivalent to $>860,000 \mathrm{t}$, with a value of $>$ U.S.\$51 million. The only other two loss estimates of which we are aware are those of Gondwe et al. (2002) (U.S.\$5 to 7 million in Malawi) and Manyong et al. (2012) (U.S.\$75 million for all affected areas of East and Southern Africa). Each of these estimates was developed using different approaches

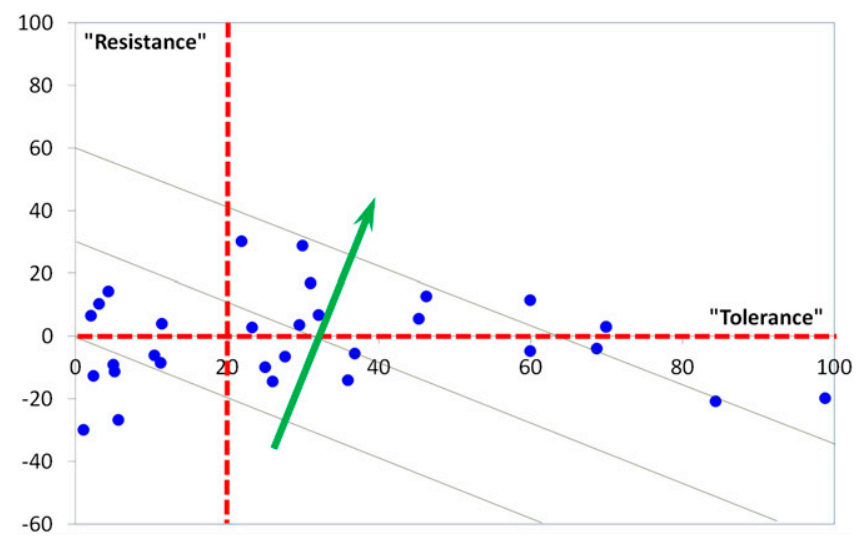

Fig. 6. Relationship between resistance and tolerance for 31 of the most commonly encountered varieties in sampled fields in the Coast and Lake Zones of Tanzania, 2009. Dotted and angled lines illustrate two alternative methods of categorizing varieties based on resistance and tolerance value pairs. In this study, the angled lines were used to split varieties into four categories: the arrow indicates the direction of improved performance (= greater tolerance and resistance). 
but all focus on field-based losses. An important future target for those aiming to increase precision in quantifying the full economic impact of CBSD will be to calculate the important social and farming system costs that are unique to this disease of cassava. Perhaps the most important of these additional costs are the opportunity cost of extra time spent carving out necrotic portions of CBSD-damaged roots during the peeling process, and the cost of replacing planting material lost as a result of early harvesting to avoid root damage. One of the key findings of the loss assessment exercise of this study was the fact that losses due to growth impairment caused by CBSD infection were approximately double those attributed to roots spoiled through root necrosis. This highlights, in a quantitative way, what has previously been suggested (Jennings 1957) but contrasts with the commonly held view that root rot is the principal source of loss caused by CBSD (Alicai et al. 2007; Bock 1994; Nichols 1950).

Results from this study have provided insights into the nature of CBSD infection of cassava varieties and the losses caused in the country most severely affected by the disease. These should be of value to cassava breeders throughout the parts of Africa affected or threatened by CBSD, and will hopefully contribute to the development of improved resistance and, ultimately, more effective management of one of Africa's most pernicious threats to food security.

\section{Acknowledgments}

The work reported in this article is an output of the activities implemented in the collaboration between the International Institute of Tropical of Agriculture (IITA) and the Ministry of Agriculture, Food Security and Cooperatives of Tanzania. We thank the Bill and Melinda Gates foundation for financial support through the Grate Lakes Cassava Initiative project and the Roots, Tubers and Bananas Program of the Consultative Group for International Agricultural Research (CGIAR); B. Chirimi, C. Bagambisa, and P. Rweyemamu from the Lake Zone and E. Liwa (Kibaha Research Station), A Njapuka (Naliendele Research Station), and A. Mohamed (Kizimbani Research Station, Zanzibar) for participating in data collection during the survey; and T. Alabi (IITA, Ibadan, Nigeria) for assistance in producing the map for Figure 1.

\section{Literature Cited}

Alicai, T., Omongo, C. A., Maruthi, M. N., Hillocks, R. J., Baguma, Y., Kawuki, R., Bua, A., Otim-Nape, G. W., and Colvin, J. 2007. Re-emergence of cassava brown streak disease in Uganda. Plant Dis. 91:24-29.

Anonymous. 2015. Tanzania: Kiroba Variety Aims to Boost Cassava Production. Online publication. http://allafrica.com/stories/201508191499.html

Bock, K. R. 1994. Studies on cassava brown streak disease in Kenya. Trop. Sci. 34: 134-145.

Childs, A. H. B. 1957. Trials with virus resistant cassava in Tanga Province, Tanganyika. East Afr. Agric. J. 23:135-137.

FAOSTAT. 2014. FAO Database. Online publication. Food and Agriculture Organisation of the United Nations, Rome. http://faostat.fao.org/site/567/default.aspx\#ancor

Gondwe, F. M. T., Mahungu, N. M., Hillocks, R. J., Raya, M. D., Moyo, C. C., Soko, M. M., Chipungu, E. P., and Benesi, I. R. M. 2002. Economic losses experienced by small-scale farmers in Malawi due to cassava brown streak virus disease. Pages 28-36 in: Cassava Brown Streak Virus Disease: Past, Present, and Future. Proc. Int. Workshop, Mombasa, Kenya. J. P. Legg and R. J. Hillocks, eds. Natural Resources International Limited, Aylesford, UK.

Government of Tanzania. 2012. National Sample Census of Agriculture 2007/2008 Smallholder Agriculture, Volume II: Crop Sector-National Report. Ministry of Agriculture, Food Security and Cooperatives, Ministry of Livestock Development and Fisheries, Ministry of Water and Irrigation, Ministry of Agriculture, Livestock and Environment, Zanzibar, Prime Minister's Office, Regional Administration and Local Governments, Ministry of Industries, Trade and Marketing, The National Bureau of Statistics and the Office of the Chief Government Statistician, Zanzibar.

Hillocks, R. J., and Jennings, D. L. 2003. Cassava brown streak disease: A review of present knowledge and research needs. Int. J. Pest Manage. 49:225-234.

Hillocks, R. J., Raya, M. D., Mtunda, K., and Kiozia, H. 2001. Effect of brown streak virus disease on yield and quality of cassava in Tanzania. J. Phytopathol. 149:389-394.

Hillocks, R. J., Raya, M. D., and Thresh, J. M. 1996. The association between root necrosis and above-ground symptoms of brown streak virus infection of cassava in southern Tanzania. Int. J. Pest Manage. 42:285-289.

Hillocks, R. J., and Thresh, J. M. 2000. Cassava mosaic and cassava brown streak virus diseases: A comparative guide to symptoms and aetiologies. Roots 7:1-8.
Jennings, D. 1957. Further studies in breeding cassava for virus resistance. East Afr. Agric. J. 22:213-219.

Jennings, D. L. 1960. Observations on virus diseases of cassava in resistant and susceptible varieties. II. Streak disease. Emp. J. Exp. Agric. 28:261-269.

Jeremiah, S. 2012. The role of whitefly (Bemisia tabaci) in the spread and transmission of cassava brown streak disease in the field. Ph.D. thesis, University of Dar es Salaam, Dar es Salaam, Tanzania.

Jeremiah, S., and Legg, J. P. 2008. Cassava Brown Streak Virus. Online publication. https://www.youtube.com/watch?v=nCJdws9CnUw

Jeremiah, S. C., Ndyetabula, I. L., Mkamilo, G. S., Haji, S., Muhanna, M. M. Chuwa, C., Kasele, S., Bouwmeester, H., Ijumba, J. N., and Legg, J. P. 2015. The dynamics and environmental influence on interactions between cassava brown streak virus disease and the whitefly, Bemisia tabaci. Phytopathol. 105:646-655.

Kaweesi, T., Kawuki, R., Kyaligonza, V., Baguma, Y., Tusiime, G., and Ferguson, M. E. 2014. Field evaluation of selected cassava genotypes for cassava brown streak disease based on symptom expression and virus load. Virol. J. 11:216.

Legg, J. P., Jeremiah, S. C., Obiero, H. M., Maruthi, M. N., Ndyetabula, I., OkaoOkuja, G., Bouwmeester, H., Bigirimana, S., Tata-Hangy, W., Gashaka, G., Mkamilo, G., Alicai, T., and Lava Kumar, P. 2011. Comparing the regional epidemiology of the cassava mosaic and cassava brown streak pandemics in Africa. Virus Res. 159:161-170.

Legg, J. P., Lava Kumar, P., Makeshkumar, T., Ferguson, M., Kanju, E., Ntawuruhunga, P., Tripathi, L., and Cuellar, W. 2015. Cassava virus diseases: Biology, epidemiology and management. Adv. Virus Res. 91:85-142.

Legg, J. P., and Raya, M. D. 1998. A survey of cassava virus disease in Tanzania. Int. J. Pest Manage. 44:17-23.

Manyong, V. M., Maeda, C., Kanju, E., and Legg, J. P. 2012. Economic damage of cassava brown streak disease in sub-Saharan Africa. Pages 61-68 in: Tropical Root and Tuber Crops and the Challenges of Globalization and Climate Change. 11th ISTRC-AB Symp. Kinshasa, Democratic Republic of Congo. R. U. Okechukwu and P. Ntawuruhunga, eds. IITA, Ibadan, Nigeria.

Maruthi, M. N., Bouvaine, S., Tufan, H. A., Mohammed, I. U., and Hillocks, R. J. 2014. Transcriptional response of virus-infected cassava and identification of putative sources of resistance for cassava brown streak disease. PLoS One 9: e96642.

Maruthi, M. N., Hillocks, R. J., Mtunda, K., Raya, M. D., Muhana, M., Kiozya, H. Rekha, A. R., Colvin, J., and Thresh, J. M. 2005. Transmission of Cassava brown streak virus by Bemisia tabaci (Gennadius). J. Phytopathol. 153:307-312.

Mbanzibwa, D. R., Tian, Y. P., Tugume, A. K., Mukasa, S. B., Tairo, F., Kyamanywa, S., Kullaya, A., and Valkonen, J. P. T. 2011a. Simultaneous virus-specific detection of the two cassava brown streak-associated viruses by RT-PCR reveals wide distribution in East Africa, mixed infections and infections in Manihot glaziovii. J. Virol. Methods 171:394-400.

Mbanzibwa, D. R., Tian, Y. P., Tugume, A. K., Patil, B. L., Yadav, J. S., Bagewadi, B., Abarshi, M. M., Alicai, T., Changadeya, W., Mkumbira, J., Muli, M. B., Mukasa, S. B., Tairo, F., Baguma, Y., Kyamanywa, S., Kullaya, A., Maruthi, M. N., Fauquet, C. M., and Valkonen, J. P. T. $2011 \mathrm{~b}$ Evolution of cassava brown streak disease-associated viruses. J. Gen Virol. 92:974-987.

Mohammed, I. U., Abarshi, M. M., Muli, B., Hillocks, R. J., and Maruthi, M. N. 2012. The symptoms and genetic diversity of cassava brown streak viruses infecting cassava in East Africa. Adv. Virol. 2012:Article ID 795697. doi: $10.1155 / 2012 / 795697$

Monger, W. A., Seal, S., Isaac, A. M., and Foster, G. D. 2001. Molecular characterization of Cassava brown streak virus coat protein. Plant Pathol. 50: 527-534.

Munga, T., and Thresh, J. M. 2002. Incidence of cassava mosaic and cassava brown streak virus diseases in coastal Kenya. Roots 8:12-14.

Nichols, R. F. J. 1950. The brown streak disease of cassava: Distribution climatic effects and diagnostic symptoms. East Afr. Agric. J. 15:154-160.

Otim-Nape, G. W., Bua, A., Thresh, J. M., Baguma, Y., Ogwal, S., Semakula, G. N., Acola, G., Byabakama, B., and Martin, A. 1997. Cassava Mosaic Virus Disease in Uganda: The Current Pandemic and Approaches to Control. Natural Resources Institute, Chatham, UK.

Patil, B. L., Legg, J. P., Kanju, E., and Fauquet, C. M. 2015. Cassava brown streak disease: A threat to food security in Africa. J. Gen. Virol. 96:956-968.

Pennisi, E. 2010. Armed and dangerous. Science 327:804-805.

Sewando, P. P. 2012. Urban markets-linked cassava value chain in Morogoro Rural Districts, Tanzania. J. Sustainable Dev. Afr. 14:283-300.

Storey, H. H. 1936. Virus diseases of East African plants-VI. East Afr. Agric. J. 2:34-39.

Thresh, J. M., and Mbwana, M. W. 1998. Cassava mosaic and cassava brown streak virus disease in Zanzibar. Roots 5:6-8.

Winter, S., Koerbler, M., Stein, B., Pietruszka, A., Paape, M., and Butgereitt, A. 2010. The analysis of cassava brown streak viruses reveals the presence of a distinct virus species causing cassava brown streak disease in East Africa. J. Gen. Virol. 91:1365-1372. 